\title{
A Benchmarking of Service Quality in Telecommunication Services: Case Study in Kurdistan Region of Iraq
}

\begin{abstract}
Ahmet Demir ${ }^{1}$
${ }^{1}$ Ishik University, Sulaimani, Iraq

Correspondence: Ahmet Demir, Ishik University, Sulaimani, Iraq.

Email: ahmet.demir@ishik.edu.iq

Received: January 6, 2019

Accepted: February 20, 2019

Online Published: March 1, 2019

doi: 10.23918/ijsses.v5i3p216

Abstract: This study aims to evaluate the comparative advantages of each GSM firm toward one another via applying benchmarking methods. To do this, a survey questionnaire has been conducted on 514 GSM service users in Kurdistan Region of Iraq. Collected data has been analyzed proposing analytic hierarchy process and VIKOR method. Based on the evaluations of the GSM service users, better and worse performing firms have been identified based on each criterion. Finally, minimum utility regret providing firm has been determined. Finally, strategic suggestions have been given to the firms according to the analysis results. The benchmarking can be used by the different policy influencing and making agencies to develop future policies for the improvement. The industry can also use the benchmarking for its peer performance improvement.
\end{abstract}

Keywords: Benchmarking, Service Quality, AHP, VIKOR, Strategic Management

\section{Introduction}

The information age has significantly increased the demand of development and use new management techniques in the 21 st century enterprises due to the rapid development of information technology, the intensification of global competition day by day, and the necessity to provide the best conditions for changing customer demands and expectations. Indeed, businesses in a global world have to produce a better-quality product at a lower cost and faster than others to maintain and enhance their competitiveness. One of the management techniques that today's businesses use to fulfill this trilogy is the "benchmarking" concept or cross-business benchmarking.

By benchmarking, businesses compete with other enterprises that are known for their excellence in the sectors they are operating in or from different sectors, bringing their best practices to business (Lee \& Kim, 2014). After that, continuous improvement is ensured, processes are improved, productivity and quality are improved, performance is improved, employee motivation is increased, and ultimately, excellent customer service can be created as a starting point for superiority in today's global competitive conditions (Min \& Min, 2015).

Strategic management for today's businesses is a process that is focused on final results such as sustaining long-term survival and sustainable competitive advantage, and benchmarking studies can be used as a tool to increase the efficiency of this process and to compare and compile the necessary information. In addition, with benchmarking activities, enterprises are on the way to become 
organizations that learn by getting new ideas from the external environment elements such as competitors, customers, sectors they are active in and they can abandon traditional strategy bases such as scale economies and specialization and increase the effectiveness of strategic management with new bases like benchmarking, learning organizations.

Telecommunication service sector in Kurdistan Region is one of the emerging sectors that provide services to fulfill the expectations of the customers. The Kurdistan Region is an autonomous region in federal Iraq that was cut off from all basic postal and telephone services after the first Gulf War in 1991. The region became dependent on satellite-based information and communication systems and services. The expansion and diffusion of these services have been rapid and promoted by the Kurdistan Regional Government (Khayyat, 2010; Khayyat \& Heshmati, 2012). From this point of view, benchmarking for the further strategic planning and management would be very useful for the telecommunication service sector firms in the region.

There are various studies of analytic hierarchy process and VIKOR method evaluating e-government websites (Burmaoglu \& Kazancioglu, 2012), airline services (Chen \& Chen, 2010), customer satisfaction in the banks (Dincer \& Hacioglu, 2013) ...etc. On the other hand, there are only few researches on benchmark service quality in the telecommunication service sector. For example, Jost (2003) has proposed a benchmarking among GSM operators for evaluating their voice quality. Debnath \& Shankar (2008) and Nigam et al., (2012) have used data envelopment analysis (DEA) to compare the relative efficiency of mobile service providers in India. In this study, we have proposed analytic hierarchy process with VIKOR method for benchmarking service quality of GSM operators based on the customer evaluations in Kurdistan Region of Iraq. Secondly, enterprises in the region are not very familiar with the scientific benchmarking and strategic management based on the data analysis. From this point of view, the study aims to lead future researches in this field in Kurdistan Region of Iraq.

The study aims to understand the weak points of each firm comparing to each other by benchmarking methodology and suggest some advises to the sector for the further strategic planning and management. To do this, we have determined main service quality dimensions of telecommunication sector in Kurdistan Region of Iraq via evaluating the literature. Secondly, proposed descriptive statistic, analytic hierarchy process and VIKOR method for benchmarking. Finally, we have proposed some strategic suggestions based on the findings of the research.

\section{Literature Review}

\subsection{Service Quality Determinants in Telecommunication Sector}

Some researchers (Wang, Lo, \& Yang, 2004; Johnson \& Sikirit, 2002; Lai, 2004)) have studied service quality in telecommunication service sector by proposing parameters of well-known SERVQUAL model, with some reasonable adjustments based on the focus group discussions and expert opinions. Izogo (2017) has used only service reliability and assurance parameters of SERVQUAL. Beside this, many researchers (Shafei \& Tabaa, 2016; Kim et al., 2004; Selnes, 1993) have emphasized the impact of network quality as one of the parameters of service quality. Network connection provides better connection and communication to the GSM service user so that it is an important parameter of the service quality. Secondly, pricing structure is an important point for the service quality which is 
estimated to significantly impact switching decision (Bolton, 1998). It is known that providing better service with the lower price will provide competitive advantage on cost to a firm. Third parameter of service quality is considered as promotions. Promotions would influence the satisfaction and the loyalty of the customers (Lee et al., 2001). Finally, conflict handling can be considered a parameter that impact the perceptions of service quality (Nwakanma, 2018). It encompasses to evaluate the processes of complaint from customers and solve them precisely and on time (Negi \& Ketena, 2013).

There is no specific agreement on the concept of service quality in telecommunication service sector (Carman, 1990). For example, many authors have investigated the service quality in different sectors variously. Taking telecommunication service sector into account, it has been found that many authors have suggested network quality (Aydin \& Ozer, 2005; Gerpott et al., 2001; Wang, Lo, \& Yang, 2004), pricing structure (Gerpott et al., 2001; Kim, Park, \& Jeong, 2004), conflict handling (Gerpott et al., 2001; Kim, Park, \& Jeong, 2004; Lee, Lee, \& Freick, 2001), and promotions (Lee, Lee, \& Freick, 2001) as service quality dimensions in telecommunication service sector so we have proposed those dimensions as essentials of service quality in this sector. From this point of view, we can estimate telecommunication service quality parameters as;

1. Network Quality (Aydin \& Ozer, 2005; Santouridis \& Trivellas, 2010): coverage area and call quality.

2. Pricing Structure (Shafei \& Tabaa, 2016): reasonable prices for calls, internet services, value added services (GPRS, VAP...etc.), inter-operator calls, and inter-operator SMS services.

3. Promotions (Kotler \& Armstrong, 2013): Extra minutes that operator gives, special days discounts, overall promotions.

4. Conflict Handling (Nwakanma, 2018): avoiding potential conflict or complaints, discuss solutions when problem arises, attempts to solve manifest conflicts before it faces problems.

\subsection{Benchmarking Service Quality}

According to Fischer (De Brujin et al., 2004) benchmarking is when the businesses want to improve the way they do business, analyze best practices and adapt it to their own activities. This definition includes four basic steps (De Brujin et al., 2004). First, performance measures are formulated, then the manufacturing process of the benchmarking entity is examined, then the findings are examined, and the differences are determined and finally the necessary changes are made in business activities based on the best practice. Mainly, there are performance, process, strategic, internal, competitive, functional, and generic benchmarking types (Butta \& Huq, 1999);

1. Performance benchmarking: It is the comparison of performance measures for the purpose of determining how good our company is when compared to others.

2. Process benchmarking: Methods and processes are compared in an effort to improve the processes in our own company.

3. Strategic benchmarking: The study is undertaken when an attempt is being made to change the strategic direction of the company and the comparison with one's competition in terms of strategy is made.

4. Internal benchmarking: When comparisons are made between departments/divisions of the same company or organization 
5. Competitive benchmarking: It is performed against "best" competition to compare performance and results

6. Functional benchmarking: A benchmarking study to compare the technology/process in one's own industry or technological area. The purpose of this type of benchmarking to become the best in that technology/ process

7. Generic benchmarking: Comparison of processes against best process operators regardless of industry

When the current service quality benchmarking literature looked up, Lin (2005) has studied stochastic cost frontier models to illustrate how quality of Peruvian water services is. Author has concluded that it is necessary to incorporate the quality variables as additional output variables rather than as environmental variables. Lee \& Kim (2014) have proposed a data envelopment analysis approach to measurement and benchmarking of service quality. They have used SERVQUAL model in auto repair services. Singh (2016) has used analytic hierarchy process for benchmarking service quality in airline industry. The researcher used competitive service quality gap analysis that helped to identify areas of service improvement and to identify strengths and weakness as compared to its competitors. Finally, he has suggested some advices to the top management for improving service quality in the sector. Hemmington, Kim \& Wang (2018) have proposed importance-performance benchmark vectors (IPBV) as a benchmarking tool and investigate its applicability in the context of hotel service quality. Kannan (2010) has proposed analytic hierarchy process for evaluating the service quality in ocean container carrying services which contained seven dimensions; rate, customer service, operations, reputation, infrastructure, scheduling and information technology orientation and communication.

In this study, we have proposed analytic hierarchy process and VIKOR (multi criteria decision making) method for benchmarking of service quality in telecommunication service sector. Analytic hierarchy process was used to calculate importance weights of each parameter. Further, VIKOR method was proposed to calculate the best performing alternative. Finally, strategic suggestions have been proposed for the further developments based on the weak points of the firms.

\subsection{Strategic Management}

Strategic management field has rapid development and fruitful results for half a century (Du \& Chen, 2018). However, when the history of the strategic management is evaluated, 1960s are seen to be initial stream of researches (Furrer et al., 2008).

Strategic management might be defined as a management technique to catch up with the market change. It leads organization to take strategic decisions and organizational steps forward for the success (Ginter et al., 2002). Strategic management activities have three main elements (Johnson et al., 2008; Jasper \& Crossan, 2008); "strategic analysis, which is concerned with understanding the strategic position of the organization; strategic choice, which is the understanding of the bases and underpinnings that guide strategic decisions; and strategy implementation concerned with translating strategy into action". Strategic management requires to evaluate problems from various aspects. Managements should evaluate changes in the market and think to have competitive advantage over other competitors.

The main activities in the strategic management process will be listed as follows (Prasnikar et al., 2005): 
Planning: The activities to be carried out in future periods and their effects on the planning stage Implementation: The planned activities to achieve actual business results in the implementation phase Control: Comparison of actual results with planned activities and if there are deviations, they will be dealt with in the stage of correction.

Strategic management focusses mainly on competitive advantage in the market (Porter, 1980; Moortel \& Crispeels, 2018). To do this, strategic management requires an assessment of a firm's internal and external environments and statistical analysis plays a very important role (Parnell, 2014) to understand the internal and external situation of a firm (Prollochs \& Feuerriegel, 2018). From this point of view, in this study, we have benchmarked the service quality of the telecommunication service providing firms in Kurdistan Region of Iraq from the customers' perspective and projected their external situation via making some statistical analysis. Further, we have given some advices based on the analyses results.

\subsection{AHP}

As we have mentioned in the previous section, statistical analysis plays an important role in strategic management and benchmarking. There are two important tools among others we have proposed in this study; analytic hierarchy process and VIKOR methods.

Analytic hierarchy process is one of the measurement theories (Saaty, 2013) that has been found by Saaty in 1980 and is used to determine the relative measurement and comparison but not absolute (Ozmen, Demir, \& Celepli, 2013). The method has been proposed in many fields such as selecting best alternative, resource selection, performance evaluation, optimization...etc. (Vidya \& Kumar, 2006). It is a multi-criteria decision analysis technique that is used to elaborate the relative priorities by comparing the alternatives in multilevel hierarchic structural bases (Gorener et al., 2012).

Main steps of analytic hierarchy process can be sequenced as (Al-Kharbi, 2001);

1. Define the problem and determine its goal.

2. Structure the hierarchy from the top (the objectives from a decision-maker's viewpoint) through the intermediate levels (criteria on which subsequent levels depend) to the lowest level which usually contains the list of alternatives.

3. Construct a set of pair-wise comparison matrices ( $\operatorname{size} n \times n$ ) for each of the lower levels with one matrix for each element in the level immediately above by using the relative scale measurement shown in Table 1 below. The pair-wise comparisons are done in terms of which element dominates the other. 
Table 1: Saaty's 1-9 scale of AHP (Saaty, 1980)

\begin{tabular}{lll}
$\begin{array}{l}\text { Intensity of } \\
\text { Importance }\end{array}$ & \multicolumn{1}{c}{ Definition } & \multicolumn{1}{c}{ Explanation } \\
\hline 1 & Equal importance & Two activities contribute equally to the objective \\
\hline 3 & Moderate importance & $\begin{array}{l}\text { Experience and judgment slightly favor one over another } \\
\text { Experience and judgment strongly favor one over } \\
\text { another }\end{array}$ \\
\hline 7 & Strong importance & $\begin{array}{l}\text { Activity is strongly favored, and its dominance is } \\
\text { demonstrated in practice }\end{array}$ \\
\hline 9 & Absolute importance & $\begin{array}{l}\text { Importance of one over another affirmed on the highest } \\
\text { possible order }\end{array}$ \\
\hline $2,4,6,8$ & Intermediate values & $\begin{array}{l}\text { Used to represent compromise between the priorities } \\
\text { listed above }\end{array}$ \\
\hline $\begin{array}{l}\text { Reciprocal } \\
\text { of above } \\
\text { non-zero } \\
\text { numbers }\end{array}$ & $\begin{array}{l}\text { If activity } \mathrm{i} \text { has one of the above non-zero numbers assigned to it when compared } \\
\text { with activity } \mathrm{j}, \text { then } \mathrm{j} \text { has the reciprocal value when compared with } \mathrm{i}\end{array}$ \\
\hline
\end{tabular}

4. There are n (n-1) judgments required to develop the set of matrices in step 3. Reciprocals are automatically assigned in each pair-wise comparison.

5. Hierarchical synthesis is now used to weight the eigenvectors by the weights of the criteria and the sum is taken over all weighted eigenvector entries corresponding to those in the next lower level of the hierarchy.

6. Having made all the pair-wise comparisons, the consistency is determined by using the eigenvalue, $\lambda_{\max }$, to calculate the consistency index, CI as follows: $C I=\left(\lambda_{\max }-n\right) /(n-1)$, where $\mathrm{n}$ is the matrix size. Judgment consistency can be checked by taking the consistency ratio (CR) of CI with the appropriate value in Table 2 below. The CR is acceptable, if it does not exceed 0.10 . If it is more, the judgment matrix is inconsistent. To obtain a consistent matrix, judgments should be reviewed and improved.

Table 2: Average Random Consistency (RI) (Saaty, 1980)

\begin{tabular}{lcccccccccc}
\hline Size of Matrix & 1 & 2 & 3 & 4 & 5 & 6 & 7 & 8 & 9 & 10 \\
\hline $\begin{array}{l}\text { Random } \\
\text { Consistency }\end{array}$ & 0 & 0 & 0.58 & 0.9 & 1.12 & 1.24 & 1.32 & 1.41 & 1.45 & 1.49 \\
\hline
\end{tabular}

7. Steps 3-6 are performed for all levels in the hierarchy

In this research, AHP was proposed to understand the adjusted weights in comparison matrix. Further, the results of the analysis would be used for the calculation of VIKOR. 


\subsection{VIKOR}

VIKOR method is one of the multi criteria decision-making analysis that determines the compromise ranking list of alternatives, compromise solutions for complex problems, and the weight stability intervals for choice stability of the compromise solution obtained with the initial given weights (Opricovic \& Tzeng, 2004). The model gives best alternative as solution that is closest to the ideal (Opricovic, 1998). Steps for the VIKOR calculation are as follows (Opricovic \& Tzeng, 2004; Sennaroglu \& Celebi, 2018);

1. Determine the best $\left(f_{i}{ }^{*}\right)$ and the worst $\left(f_{i}^{-}\right)$values among all alternatives $(j=1,2,3, \ldots \ldots m)$ and by each criterion $(i=1,2,3, \ldots . . n)$.

a. If it is a benefit criterion that is to be maximized: $f_{i}^{*}=\operatorname{Max}_{j} f_{i j}$

b. If it is a benefit criterion that is to be minimized: $f_{i}^{-}=\operatorname{Min}_{j} f_{i j}$

2. Compute $S_{j}$ (Eq. (1)) and $R_{j}$ (Eq. (2)) for $j=1,2,3 \ldots m$. $S_{j}$ and $R_{j}$ respectively represent utility and regret measures for alternative.

$$
\begin{aligned}
& \mathrm{S}_{\mathrm{j}}=\sum_{j=1}^{n}\left[w_{i}\left(\frac{f_{i}{ }^{*}-f_{i j}}{f_{i}{ }^{*}-f_{i}{ }^{-}}\right)\right] \\
& \mathrm{R}_{\mathrm{j}}=\sum_{j=1}^{n} \max _{j}\left[w_{i}\left(\frac{f_{i}{ }^{*}-f_{i j}}{f_{i}{ }^{*}-f_{i}{ }^{-}}\right)\right]
\end{aligned}
$$

Where wi is the weight of the criterion

3. Compute $Q_{j}$ (Eq. (3)) for $j=1,2,3 \ldots, m$

a. where $S^{*}=\min S_{j}, S^{-}=\max S_{j}, R^{*}=\min R_{j}, R^{-}=\max R_{j}, v$ is the weight for the decision making strategy of the maximum group utility and $(1-\mathrm{v})$ is the weight of the individual regret; generally $\mathrm{v}$ is assumed equal 0.5 corresponding to by consensus.

$$
\mathrm{Q}_{\mathrm{i}}=\sum_{j=1}^{n}\left[\mathrm{v}\left(\frac{S_{i}-S_{i}^{-}}{S_{i}{ }^{*}-S_{i}{ }^{-}}\right)+(1-\mathrm{v})\left(\frac{R_{i}-R^{-}}{R^{*}-R^{-}}\right)\right]
$$

4. Rank the alternatives by the values $\mathrm{S}, \mathrm{R}$ and $\mathrm{Q}$ in ascending order by forming three ranking lists such that the lower the value the better the alternative.

5. Propose the alternative $\mathrm{a}^{\prime}$ as a compromise solution which is ranked the best by the minimum value of $\mathrm{Q}$ if the following two conditions are satisfied:

i. Condition 1. Acceptable advantage: $Q\left(a^{\prime \prime}\right)-Q\left(a^{\prime}\right) \geqslant D Q$ where $a^{\prime \prime}$ is the alternative which is ranked second by $\mathrm{Q}$ and $D Q=1 /\left(m^{-1}\right)$.

ii. Condition 2. Acceptable stability in decision making: Alternative $a^{\prime}$ must also be the best ranked by $\mathrm{S}$ or/and $\mathrm{R}$.

6. If one of the conditions in Step 5 is not satisfied, propose a set of compromise solutions which include:

a. Alternatives $\mathrm{a}^{\prime}$ and $\mathrm{a}^{\prime \prime}$ if only Condition 2 is not satisfied, or

b. Alternatives $a^{\prime}, a^{\prime \prime}, \ldots, a(n)$ if only Condition 1 is not satisfied; the closeness of the alternative $\mathrm{a}(\mathrm{n})$ ranked $\mathrm{nth}$ by $\mathrm{Q}$ is determined by $\mathrm{Q}(\mathrm{a}(\mathrm{n}))-\mathrm{Q}\left(\mathrm{a}^{\prime}\right)<\mathrm{DQ}$. 


\section{Methodology}

This study aims to benchmark service quality of the telecommunication service providing firms in Kurdistan Region of Iraq. For benchmarking, we first prepared a survey questionnaire which contained questions under network quality, promotions, pricing structures, conflict handling, trust, corporate image, satisfaction and loyalty. These dimensions were abstracted from previous studies in the field. The structured dimensions were discussed with regional general directors of GSM service providers. These meetings also involved human resource managers, marketing managers and strategic management managers. They have determined the importance of each dimension for the sector and evaluated the appropriateness of the questionnaire. The survey questionnaire was finalized after these discussions. We selected the Likert scale for our analysis where 1 means "strongly disagree" and 5 "strongly agree".

The survey questionnaire was administered in 2018 to 650 telecommunication services users in the region through face-to-face meetings. The participants were selected randomly in shopping malls, cafés and bus stations; 136 of the participants' answers had to be discarded due to incomplete and irrelevant answers. We used the remaining 514 participants' answers for the statistical analysis. Table 3 gives the profile of the participants by gender, nationality and monthly income.

Table 3: Profile of Participants

\begin{tabular}{|lc|lc|lc|}
\hline Subsample & Proportion & Nationality & Proportion & Income (USD) & $\begin{array}{c}\text { Proportio } \\
\mathrm{n}\end{array}$ \\
\hline Male & $43 \%$ & Kurdish & $84 \%$ & $<1,000$ & $68 \%$ \\
Female & $55 \%$ & Turkmen & $10 \%$ & $1,000-2,000$ & $24 \%$ \\
Missing & $2 \%$ & Arab & $5 \%$ & $2,000-3,000$ & $6 \%$ \\
& & Missing & $1 \%$ & $>3,000$ & $2 \%$ \\
\hline
\end{tabular}

We have used IBM SPSS 23, Expert choice 11, and Microsoft office excel 2013 to analyze obtained data. Initially, we have calculated the relative weights of each dimension to one another. Analytic hierarchy process was employed in this section. Secondly, descriptive statistics have been abstracted from participants' evaluation of network quality, promotion, pricing structure, and conflict handling dimensions. VIKOR method has been employed to calculate the best alternative. Finally, strategic suggestions have been given to the service providers in the field.

\subsection{Findings}

\subsubsection{AHP}

While proposing multi criteria decision analysis, structuring decision criteria in a hierarchical form plays a very important role for successful decision analysis (Saaty, 1994). Structuring criteria in hierarchical form provides an overall view of a complex relation between each one. There is no specified process for structuring each criterion hierarchically (Kannan, 2010). Thus, like many authors (Ozmen, Ahmet \& Celepli, 2013; Wu \& Tsai, 2011; Kannan, 2010), we have determined the hierarchy between each criteria and sub criteria via discussions with experts in GSM service providing firms. 
Table 4: Pairwise comparison weights of criteria

\begin{tabular}{lcccc}
\hline Criterion & Conflict Handling & Pricing Structure & Network Quality & Promotions \\
\hline Conflict Handling & 1 & 3 & 5 & 7 \\
Pricing Structure & $1 / 3$ & 1 & 2 & 3 \\
Network Quality & $1 / 5$ & $1 / 2$ & 1 & 3 \\
Promotions & $1 / 7$ & $1 / 3$ & $1 / 3$ & 1 \\
\hline \multicolumn{5}{c}{ Note: Consistency Ratio: 0.07} \\
\hline
\end{tabular}

Table 4 above shows the pairwise comparison weights of criteria. The entries in the diagonal 1s show that two same criterions are compared. In this case there can be no priority and they are in the same level of the hierarchy. Remaining numbers show priority or importance of a criterion to another. The comparison matrix has been completed after the discussions with experts in three telecommunication service companies. Further, the weights have been normalized by dividing hierarchy value of a criteria by column sum and total of the normalized weights in the concerning column add up to 1 . All values of the normalized weights have been presented on the Table 5.

Table 5: Relative priority and weights of criteria

\begin{tabular}{lccrrr}
\hline Criteria & $\begin{array}{c}\text { Conflict } \\
\text { Handling }\end{array}$ & $\begin{array}{r}\text { Pricing } \\
\text { Structure }\end{array}$ & $\begin{array}{r}\text { Network } \\
\text { Quality }\end{array}$ & Promotions & Weight \\
\hline Conflict & 0.597 & 0.662 & 0.536 & 0.438 & 0.558 \\
Handling & 0.199 & 0.221 & 0.321 & 0.313 & 0.264 \\
Pricing Structure & 0.119 & 0.074 & 0.107 & 0.188 & 0.122 \\
Network Quality & 0.085 & 0.044 & 0.036 & 0.063 & 0.057 \\
Promotions & Note: Consistency Ratio: 0.044 \\
\hline \multicolumn{7}{l}{} \\
\hline
\end{tabular}

Total of normalized weights of each criterion represent the relative priority regarding to other criteria in the hierarchy. According to the results, the most important criterion, conflict handling has weight of 55.8 percent, which is followed by pricing structure with the value of 26.4 percent, network quality and promotions with the weights of 12.2 percent and 5.7 percent, respectively. In order to elaborate weight in detail, sub criteria of each criterion have been calculated. The calculation has been done with the same methodology as it was in Table 5.

Table 6 mainly shows the relative priority within the concerning criterion. For example, there are two main criteria for network quality. Call quality and coverage area have been discussed with the experts and concluded that call quality is slightly more important than coverage area. As result, relative weight of call quality and coverage area is 0.667 and 0.333 , respectively. In order to find the relative priority of call quality, normalized weight of global sub criteria have been multiplied by the overall global weight of the main criteria. As result, relative weight of call quality (NQ2) within the network quality has been obtained as 0.081. with the same methodology, coverage area (NQ1) was 0.041. So that summation of relative weights of both sub criterion will equal to the global weight of the main criterion which is 0.122 . The relative weights of other sub criterions have been calculated with the same methodology. 
Table 6: Normalized weights of sub criterions within the main criterion

\begin{tabular}{|c|c|c|c|c|}
\hline Criterion & Sub Criterion & $\begin{array}{r}\text { Global } \\
\text { Weights } \\
\text { of Criterion }\end{array}$ & $\begin{array}{r}\text { Weight of } \\
\text { Sub Criterion }\end{array}$ & $\begin{array}{r}\text { Relative } \\
\text { Weights of } \\
\text { Sub Criterion }\end{array}$ \\
\hline \multirow{2}{*}{ 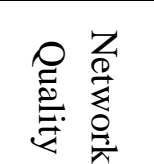 } & Coverage Area (NQ1) & 0.122 & 0.333 & 0.041 \\
\hline & Call Quality (NQ2) & 0.122 & 0.667 & 0.081 \\
\hline \multirow{5}{*}{ 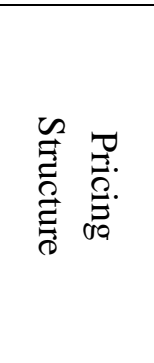 } & GSM call prices (PS1) & 0.264 & 0.427 & 0.113 \\
\hline & Internet services prices (PS2) & 0.264 & 0.063 & 0.017 \\
\hline & $\begin{array}{l}\text { Prices of value-added services (GPRS, } \\
\text { WAP...etc.) (PS3) }\end{array}$ & 0.264 & 0.094 & 0.025 \\
\hline & Prices of inter-operator calls (PS4) & 0.264 & 0.254 & 0.067 \\
\hline & $\begin{array}{l}\text { Prices of inter-operator messaging } \\
\text { services (PS5) }\end{array}$ & 0.264 & 0.162 & 0.043 \\
\hline \multirow{3}{*}{ 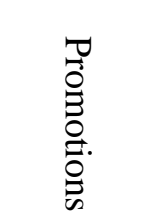 } & Extra minutes (PR1) & 0.057 & 0.540 & 0.031 \\
\hline & Special day discounts (PR2) & 0.057 & 0.163 & 0.009 \\
\hline & Overall Promotions (PR3) & 0.057 & 0.297 & 0.017 \\
\hline \multirow{3}{*}{ 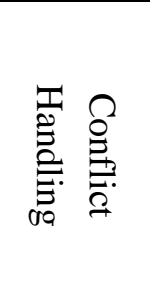 } & $\begin{array}{l}\text { Avoiding potential conflict/complaint } \\
(\mathrm{CH} 1)\end{array}$ & 0.558 & 0.648 & 0.362 \\
\hline & $\begin{array}{l}\text { Discussing solutions when problems } \\
\text { arise }(\mathrm{CH} 2)\end{array}$ & 0.558 & 0.122 & 0.068 \\
\hline & $\begin{array}{l}\text { Attempts to solve manifest conflicts } \\
\text { before it faces problems }(\mathrm{CH} 3)\end{array}$ & 0.558 & 0.230 & 0.128 \\
\hline
\end{tabular}

\subsubsection{VIKOR}

In order to propose benchmarking among GSM operators in Kurdistan Region of Iraq, questionnaire results obtained from the GSM service users was considered. Participants have rated the service performance of their GSM operators at each criterion. Further, the averages of the participants for each service provider have been calculated. For each sub criterion, best average value $\left(\mathrm{f}_{\mathrm{i}}^{*}\right)$ and the worst average value $\left(f_{i}^{-}\right)$have been determined. $S j$ and $\mathrm{Rj}$ values for each service provider have been calculated using equations (1) and (2) respectively. 
Table 7: $\mathrm{Sj}$ and $\mathrm{Rj}$ values of service providers at each sub criterion

\begin{tabular}{|c|c|c|c|c|c|c|c|c|c|c|}
\hline CR & SC & $\mathrm{COM}$ & $\mathrm{N}$ & M & GWC & GWSC & RWSC & $\mathrm{F}_{\mathrm{i}}^{*}$ & $\mathrm{~F}_{\mathrm{i}}^{-}$ & $\mathrm{RS}_{\mathrm{j}}$ \\
\hline \multirow{6}{*}{ 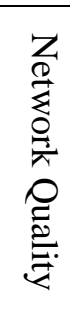 } & NQ1 & orek & 167 & 2.665 & 0.122 & 0.333 & 0.041 & 2.851 & 2.665 & 0.041 \\
\hline & & Asia Cell & 276 & 2.851 & 0.122 & 0.333 & 0.041 & 2.851 & 2.665 & 0.000 \\
\hline & & Zen Telecom & 71 & 2.717 & 0.122 & 0.333 & 0.041 & 2.851 & 2.665 & 0.029 \\
\hline & NQ2 & Korek & 167 & 3.000 & 0.122 & 0.667 & 0.081 & 3.183 & 3.000 & 0.081 \\
\hline & & Asia Cell & 276 & 3.109 & 0.122 & 0.667 & 0.081 & 3.183 & 3.000 & 0.033 \\
\hline & & Zen Telec & 71 & 3.183 & 0.122 & 0.667 & 0.081 & 3.183 & 3.000 & 0.000 \\
\hline \multirow{15}{*}{ 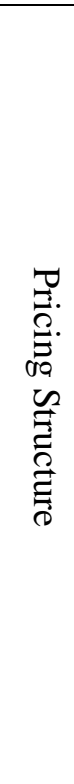 } & PS1 & Korek & 167 & 2.707 & 0.264 & 0.427 & 0.113 & 2.880 & 2.707 & 0.113 \\
\hline & & Cell & 276 & 2.880 & 0.264 & 0.427 & 0.113 & 2.880 & 2.707 & 0.000 \\
\hline & & Zen Telecc & 71 & 2.833 & 0.264 & 0.427 & 0.113 & 2.880 & 2.707 & 0.030 \\
\hline & PS2 & Korek & 167 & 2.695 & 0.264 & 0.063 & 0.017 & 2.983 & 2.695 & 0.017 \\
\hline & & Cell & 276 & 2.960 & 0.264 & 0.063 & 0.017 & 2.983 & 2.695 & 0.001 \\
\hline & & Zer & 71 & 2.983 & 0.264 & 63 & 17 & 2.983 & 2.695 & 0.000 \\
\hline & PS3 & Korek & 167 & 2.868 & 0.264 & 0.094 & 0.025 & 3.033 & 2.868 & 0.025 \\
\hline & & Asia Cell & 276 & 2.920 & 0.264 & 0.094 & 0.025 & 3.033 & 2.868 & 0.017 \\
\hline & & Zen & 71 & 3.033 & 0.264 & 0.094 & 0.025 & 3.033 & 2.868 & 0.000 \\
\hline & PS4 & Ko & 167 & 2.802 & 64 & 54 & 0.067 & 2.933 & 2.802 & 0.067 \\
\hline & & Asia Cell & 276 & 2.891 & 0.264 & 0.254 & 0.067 & 2.933 & 2.802 & 0.021 \\
\hline & & Zen Tele & 71 & 2.933 & 0.264 & 0.254 & 0.067 & 2.933 & 2.802 & 0.000 \\
\hline & PS5 & Korek & 167 & 2.790 & 0.264 & 0.162 & 0.043 & 3.051 & 2.790 & 0.043 \\
\hline & & A & 276 & 3.051 & 0.264 & & & 3.051 & 2.790 & 0.000 \\
\hline & & Zen Tel & 71 & 2.833 & 0.264 & 62 & 0.043 & 3.051 & 2.790 & 0.036 \\
\hline \multirow{9}{*}{ 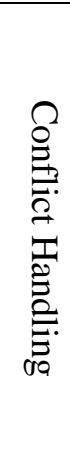 } & $\mathrm{H1}$ & Korek & 167 & 2.760 & 0.558 & 0.648 & 0.362 & 3.067 & 2.760 & 0.361 \\
\hline & & Cell & 276 & 2.957 & 0.558 & 0.648 & 0.362 & 3.067 & 2.760 & 0.130 \\
\hline & & $\mathrm{Ze}$ & 71 & 3.067 & & & & 3.067 & 2.760 & 0.000 \\
\hline & $\mathrm{CH} 2$ & Korek & 167 & 2.820 & 0.5 & 22 & 0 . & 3.150 & 2.820 & 0.068 \\
\hline & & Asia Cell & 276 & 2.851 & 0.558 & 0.122 & 0. & 3.150 & 2.820 & 0.062 \\
\hline & & Zen Telecom & 71 & 3.150 & 0.558 & 0.122 & 0.068 & 3.150 & 2.820 & 0.000 \\
\hline & $\mathrm{CH} 3$ & Korek & 167 & 2.695 & 0.558 & 0.230 & 0.128 & 3.050 & 2.695 & 0.128 \\
\hline & & Asia Cell & 276 & 2.888 & 0.558 & 0.230 & 0.128 & 3.050 & 2.695 & 0.059 \\
\hline & & Zer & 71 & 3.050 & & 0.230 & 0.128 & 3.050 & 2.695 & 0.000 \\
\hline \multirow{9}{*}{ 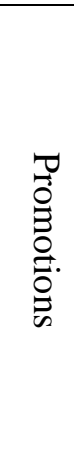 } & PR1 & Korek & 167 & 2.928 & 0.057 & 0.540 & 0.031 & 3.017 & 2.928 & 0.031 \\
\hline & & Asia Cell & 276 & 2.949 & 0.057 & 0.540 & 0.031 & 3.017 & 2.928 & 0.023 \\
\hline & & Zen Telec & 71 & 3.017 & 0.057 & 0.540 & 0.031 & 3.017 & 2.928 & 0.000 \\
\hline & PR2 & Korek & 167 & 2.844 & 0.057 & 0.163 & 0.009 & 2.964 & 2.844 & 0.009 \\
\hline & & & 276 & 2.964 & 0.057 & 0.163 & 0.009 & 2.964 & 2.844 & 0.000 \\
\hline & & Zen Telecom & 71 & 2.867 & 0.057 & 0.163 & 0.009 & 2.964 & 2.844 & 0.008 \\
\hline & PR3 & Korek & 167 & 2.856 & 0.057 & 0.297 & 0.017 & 3.200 & 2.856 & 0.017 \\
\hline & & Asia Cell & 276 & 3.043 & 0.057 & 0.297 & 0.017 & 3.200 & 2.856 & 0.008 \\
\hline & & Zen Telecom & 71 & 3.200 & 0.057 & 0.297 & 0.017 & 3.200 & 2.856 & 0.000 \\
\hline
\end{tabular}


Note: CR: criterion, SC: Sub Criterion, COM: Competitors, N: Number of participants, GWC: Global weight of criterion, GWSC: Global weight of Sub criterion, RWSC: Relative weight of sub criterion, $\mathrm{F}_{\mathrm{i}}^{*}$ : Best value among competitors, $F_{i}^{-}$: Worst value among competitors $\mathrm{RSj}=$ Relative weights for utility regret

As result of these calculations, relative utility regret $(\mathrm{RSj})$ has been obtained. The relative utility regret shows how much the users would be regretful for the concerning criterion if they select that GSM service provider. For example, coverage area (NQ1) is a criterion which is relatively important for customers. Considering GSM Firm, A, B, and C, it was observed that the relative utility regret values were 0.041, 0.00, and 0.029, respectively. It shows that the user, who selects Asia Cell, would have the least utility regret among others. The results show that Asia Cell has utility regret 0.00 which is relatively less than Korek (0.041) and Asia Cell (0.029). The other relative utility regret criterions have been calculated with the same methodology. All the further details are in Table 7.

Secondly, Global $\mathrm{Sj}$ and Global $\mathrm{Rj}$ values have been calculated by adding up all $\mathrm{Sj}$ values for each competitor at each sub criterion and $\mathrm{Rj}$ values for each competitor at each sub criterion. For example, in order to calculate $\mathrm{Sj}$ value for Korek, we have added up all $\mathrm{Sj}$ values of the firm from Table 7. Further, for the $\mathrm{Rj}$ values, we have selected maximum values among all $\mathrm{Sj}$ values of the brand from the same table. Other $\mathrm{Sj}$ and $\mathrm{Rj}$ values for each service provider have been calculated respectively with the same methodology. Finally, Qj values for each alternative have been calculated by using equation (3). For this calculation, we have used "V" vector value as 0.5 like other authors (Opricovic \& Tzeng, 2004; Sennaroglu \& Celebi, 2018). The results of the calculation can be observed on the Table 8 .

Table 8: Final values of alternatives for benchmarking

\begin{tabular}{lccccccc}
\hline Alternatives & $\mathrm{Sj}$ & $\mathrm{Rj}$ & $\mathrm{Sj} *$ & $\mathrm{Sj}-$ & $\mathrm{Rj} *$ & $\mathrm{Rj}-$ & $\mathrm{Qj}$ \\
\hline Korek & 1.000 & 0.361 & & & & & 1.000 \\
Asia Cell & 0.354 & 0.130 & 0.103 & 1.000 & 0.036 & 0.361 & 0.640 \\
Zen Telecom & 0.103 & 0.036 & & & & & 0.000 \\
\hline
\end{tabular}

The results of global utility regret $(\mathrm{Sj})$ and $(\mathrm{Rj})$ values show consistency with the maximum utility $(\mathrm{Qj})$ that Zen Telecom is the best service quality providing firm rather than Asia Cell and Korek based on the evaluations of service users. However, $\mathrm{C} 1\left(\mathrm{Q}_{\text {Zen Telecom- }} \mathrm{Q}_{\text {Asia Cell }} \geq 1 / 3-1\right)$ and $\mathrm{C} 2$ (that Zen Telecom is best ranked by $\mathrm{Rj}$ and $\mathrm{Sj}$ ) criteria have been satisfied.

\section{Practical Implications (Strategic Planning)}

There are several implications of the current study. First, by using the current framework, GSM operators may see their level of service quality relatively with the other competitors. Such benchmarking exercises are somehow lacking in Kurdistan Region of Iraq and this paper plays an important role from this point of view.

Secondly, the study shows determinants of service quality in telecommunication service sector. From this point, the study helps practitioners to understand the service dimensions of service quality in the sector while they compare to each other. It must be known that if a firm gives incorrect weights to 
incorrect criterions, the analysis results may mislead firm in the future for the strategic planning phase and even loss of service users.

Third, firms may compare quality of their sub services in detail with each other and make a small SWOT analysis from those aspects. As the paper determined very precise criterions of the service quality in GSM service sector, top management of the firms in the sector may use the same methodology to see their strong and weak points in comparison with the other operators.

Finally, they may state their strategic plan in order to achieve competitive advantage over other competitors. For example, if top management knows some realities about the firm, they may better understand how to allocate and invest financial resources, human resources, and points to improve further.

Considering network quality, conflict handling, promotions, and pricing structure, Korek demonstrates poor performing than the competitors. For example, coverage area of the firm has the maximum of the utility regret (0.041). This shows that the coverage area of the GSM operator is poor, and the users are less satisfied with it than the users of other GSM operators. Consequently, call quality also has more utility regret coefficient than other operators. From these points of view, the operator had better take some strategic actions to improve their network quality. To do this, they may quantify the number of satellites they have established so far and put a strategic aim within a period of time to increase the number of the satellites. Beside this, Zen Telecom demonstrates best performing in coverage area and call quality because they have the least utility regret coefficients 0.00 for both. Thus, strategy for them might be keeping this position in the market continuously and even increasing the quality to the further. Considering the evaluation results based on the coverage area and call quality, although Zen Telecom had the best position rather than other two operators, they still are not well above average (three) value of satisfaction by users. Hence, they need to improve their quality to become absolute the best operator in the coverage area and the network quality points of view.

Another point for evaluation is conflict handling. As it has been observed that conflict handling is the most important dimension in telecommunication service sector in Kurdistan Region of Iraq, firms should pay utmost attention for the customer satisfaction, corporate image, and further for the loyalty. When the GSM operators have been evaluated from the conflict handling point, it was observed that Zen Telecom was better performing than Asia Cell and Korek. On the other hand, Korek was worse than Asia Cell and Zen Telecom. From this point of view, firms may increase the technical human resources who are expert in the field for maintenance and repair. Moreover, for the call centers they may increase the number of human resources who are expert in communication skills and problem solving. Firms may even randomly call their customers periodically to get feedback about their satisfaction from the service they receive.

Like evaluation made in the previous paragraphs, firms may evaluate their position and determine some strategic goals to improve their weak points. As customers are the main and the most important evaluators of any service, their consideration and evaluation results have been used for this study. From this point of view, GSM operators may benchmark their services from more various aspects such as trust, corporate image, switching cost, satisfaction, and loyalty. 


\section{Conclusions, Limitations, and the Directions for the Future Researches}

This research studied to benchmark GSM service operators from various aspects of service quality such as network quality, pricing structure, promotions, and conflict handling. To do this, data have been obtained from GSM service users via survey questionnaire. Survey questionnaire has included all criterions to be compared with each service operator. Customers have evaluated each firm from various aspects of service quality which have been determined as important by experts of the telecommunication service sector.

Initially, analytic hierarchy process has been used to determine the relative and global weights of each criterion and sub criterion. Secondly, VIKOR method has been proposed to benchmark each service provider based on the sub criterions which have been determined by the experts.

Results have shown that Zen Telecom is better performing than other telecommunication service providers overall. Beside this, Korek has been worse than the competitors. When the results are evaluated in detail, it can be seen that there are some service quality criterions that Asia Cell performs better than $\mathrm{C}$ and vice versa. According to these results, firms can perform self-evaluation and propose a strategic planning for their further improvement. The study is important for the region in order to increase the spirit of competition and benchmarking. If the firms evaluate each other and develop strategies for the competitive advantage, more scientific and competitive atmosphere may provide customers better services in lower prices. From this point, the study closes a gap.

As every research, the study has limitations with the suggestions for the further studies. First, benchmarking has been proposed based on the service quality evaluation of the customers. On the other hand, performance of human resources, suppliers, and the system processes also play important role for overall performance of the firm. Thus, further researches can be proposed in the concerning points in the field. Another limitation of the study is methodology. In this study, we have proposed only AHP and VIKOR models. For the researches in the future, various competitive methods such as ELECTRE, TOPSIS, DEMATEL, PROMETHEE...etc. with the fuzzy technique. Those kinds of comparative studies might increase reliability of the calculations. Finally, AHP method requires experts' "subjective" evaluations of importance for each dimension for problem solving. On the other hand, service quality is such a parameter that customers' ideas are very critical. From this point of view, future studies may integrate structural equations modeling with VIKOR for determining weights in service quality and benchmarking.

\section{References}

Aydin, S., \& Özer, G. (2005). The analysis of antecedents of customer loyalty in the Turkish mobile telecommunication market. European Journal of marketing, 39(7/8), 910-925.

Al-Harbi, K. M. A. S. (2001). Application of the AHP in project management. International Journal of Project Management, 19(1), 19-27.

Bolton, R. N. (1998). A dynamic model of the duration of the customer's relationship with a continuous service provider: The role of satisfaction. Marketing Science, 17(1), 45-65.

Bhutta, K. S., \& Huq, F. (1999). Benchmarking-best practices: An integrated approach. Benchmarking: An International Journal, 6(3), 254-268. 
Burmaoglu, S., \& Kazancoglu, Y. (2012). E-government website evaluation with hybrid MCDM method in fuzzy environment. International Journal of Applied Decision Sciences, 5(2), 163-181.

Carman, J. M. (1990). Consumer perceptions of service quality: An assessment of T. Journal of Retailing, 66(1), 33.

Chen, J. K., \& Chen, I. S. (2010). Aviatic innovation system construction using a hybrid fuzzy MCDM model. Expert Systems with Applications, 37(12), 8387-8394.

De Brujin, Hans, Ruben V. De Joode., \& Haiko V. Der Voort (2004). Potentials and Risks of Benchmarking. Journal of Environmental Assessment Policy and Management, 6(3), 289-309.

De Moortel, K., \& Crispeels, T. (2018). International university-university technology transfer: Strategic management framework. Technological Forecasting and Social Change.

Dincer, H., \& Hacioglu, U. (2013). Performance evaluation with fuzzy VIKOR and AHP method based on customer satisfaction in Turkish banking sector. Kybernetes, 42(7), 1072-1085.

Du, J., \& Chen, Z. (2018). Applying Organizational Ambidexterity in strategic management under a "VUCA" environment: Evidence from high tech companies in China. International Journal of Innovation Studies, 2(1), 42-52.

Görener, A., Toker, K., \& Ulucay, K. (2012). Application of combined SWOT and AHP: A case study for a manufacturing firm. Procedia-Social and Behavioral Sciences, 58, 1525-1534.

Ginter P.M., Swayne L.E., \& Duncan W.J. (2002). Strategic management of healthcare organizations. 4th edition. Jossey Bass, San Francisco, CA.

Hemmington, N., Kim, P. B., \& Wang, C. (2018). Benchmarking hotel service quality using twodimensional importance-performance benchmark vectors (IPBV). Journal of Service Theory and Practice, 28(1), 2-25.

Izogo, E. E. (2017). Customer loyalty in telecom service sector: The role of service quality and customer commitment. The TQM Journal, 29(1), 19-36.

Jasper, M., \& Crossan, F. (2012). What is strategic management? Journal of Nursing Management, 20(7), 838-846.

Johnson G., Scholes K., \& Whittington R. (2008). Exploring corporate strategy. London: Prentice Hall.

Johnson, W. C., \& Sirikit, A. (2002). Service quality in the Thai telecommunication industry: a tool for achieving a sustainable competitive advantage. Management Decision, 40(7), 693-701.

Jost, H. (2003). Benchmarking GSM voice quality Denmark operators. Center for TeleInformation [interaktyvus], 20.

Kannan, V. (2010). Benchmarking the service quality of ocean container carriers using AHP. Benchmarking: An International Journal, 17(5), 637-656.

Kim, M. K., Park, M. C., \& Jeong, D. H. (2004). The effects of customer satisfaction and switching barrier on customer loyalty in Korean mobile telecommunication services. Telecommunications Policy, 28(2), 145-159.

Lai, T. L. (2004). Service quality and perceived value's impact on satisfaction, intention and usage of short message service (SMS). Information Systems Frontiers, 6(4), 353-368.

Lee, J., Lee, J., \& Feick, L. (2001). The impact of switching costs on the customer satisfaction-loyalty link: mobile phone service in France. Journal of Services Marketing, 15(1), 35-48.

Lee, H., \& Kim, C. (2014). Benchmarking of service quality with data envelopment analysis. Expert Systems with Applications, 41(8), 3761-3768.

Liang, Y. (2005). An Essential Management Tool Benchmarking has helped corporations and can help parks and recreation in the same way. Parks and Recreation-West Virginia, 40(12), 22.

Lin, C. (2005). Service quality and prospects for benchmarking: evidence from the Peru water sector. Utilities Policy, 13(3), 230-239.

Negi, R., \& Ketema, E. (2013). Customer-perceived relationship quality and satisfaction: A case of Ethiopian Telecommunication Corporation. African Journal of Economic and Management Studies, 4(1), 109-121. 
Nigam, V., Thakur, T., Sethi, V. K., \& Singh, R. P. (2012). Benchmarking of Indian mobile telecom operators using DEA with sensitivity analysis. Benchmarking: An International Journal, 19(2), 219-238.

Min, H., \& Min, H. (2015). Benchmarking the service quality of airlines in the United States: an exploratory analysis. Benchmarking: An International Journal, 22(5), 734-751.

Mitra Debnath, R., \& Shankar, R. (2008). Benchmarking telecommunication service in India: an application of data envelopment analysis. Benchmarking: An International Journal, 15(5), 584598.

Opricovic, S., \& Tzeng, G. H. (2004). Compromise solution by MCDM methods: A comparative analysis of VIKOR and TOPSIS. European Journal of Operational Research, 156(2), 445-455.

Opricović, S. (1998). VIKOR method. Multicriteria optimization of civil engineering systems. University of Belgrade-Faculty of Civil Engineering, Belgrade, 142-175.

Özmen, Ö., Demir, A., \& Celepli, M. (2013). An Analysis of Iraq's Pre-import Inspection, Testing \& Certification Program: A’WOT Analysis. Procedia-Social and Behavioral Sciences, 99, 85-93.

Parnell, J.A. (2014). Strategic management: Theory and practice. 4th ed. SAGE Publications, Inc., California.

Porter, M. E. (1980). Competitive strategy. New York: The Free Press.

Prasnikar, J., Ziga, D., \& Ahcan, A. (2005). Benchmarking as a tool of strategic management. Total Quality Management, 16(2), 257-274.

Pröllochs, N., \& Feuerriegel, S. (2018). Business analytics for strategic management: Identifying and assessing corporate challenges via topic modeling. Information \& Management.

Sennaroglu, B., \& Celebi, G. V. (2018). A military airport location selection by AHP integrated PROMETHEE and VIKOR methods. Transportation Research Part D: Transport and Environment, 59, 160-173.

Saaty, T. L. (1994). How to make a decision: The analytic hierarchy process. Interfaces, 24(6), 19-43.

Saaty, T. L. (2013). Analytic hierarchy process. In Encyclopedia of operations research and management science (pp. 52-64). Springer, Boston, MA.

Santouridis, I., \& Trivellas, P. (2010). Investigating the impact of service quality and customer satisfaction on customer loyalty in mobile telephony in Greece. The TQM Journal, 22(3), 330343.

Selnes, F. (1993). An examination of the effect of product performance on brand reputation, satisfaction and loyalty. European Journal of Marketing, 27(9), 19-35.

Saxena, V., Thakur, T., \& Singh, R. P. (2009). Efficiency Analysis and Benchmarking of Telecommunication Sector In India. In Computational Intelligence, Modelling and Simulation, 2009. CSSim'09. International Conference on (pp. 270-275). IEEE.

Shafei, I., \& Tabaa, H. (2016). Factors affecting customer loyalty for mobile telecommunication industry. EuroMed Journal of Business, 11(3), 347-361.

Singh, A. K. (2016). Competitive service quality benchmarking in airline industry using AHP. Benchmarking: An International Journal, 23(4), 768-791.

Wang, Y., Lo, H. P., \& Yang, Y. (2004). An integrated framework for service quality, customer value, satisfaction: Evidence from China's telecommunication industry. Information Systems Frontiers, 6(4), 325-340.

Wu, H. H., \& Tsai, Y. N. (2012). An integrated approach of AHP and DEMATEL methods in evaluating the criteria of auto spare parts industry. International Journal of Systems Science, 43(11), 21142124.

Zeithaml, V. A. (1988). Consumer perceptions of price, quality, and value: a means-end model and synthesis of evidence. The Journal of Marketing, 2-22. 